\title{
Pregnancy, Genetic Risk and Congenital Heart Disease
}

\section{Authors: Christine H. Attenhofer Jost*, Heidi M. Connolly\#}

*Cardiovascular Center, Klinik Im Park, Zurich, Switzerland

\#Division of Cardiovascular Diseases, Mayo Clinic, Rochester MN, USA

Address for correspondence:

Dr. Heidi M. Connolly

Division of Cardiovascular Diseases

Mayo Clinic

200 First Str SW

Rochester, MN 55905, USA

Email:

connolly.heidi@mayo.edu

ABSTRACT An increasing number of women with congenital heart disease (CHD) are reaching childbearing age and are considering pregnancy. Pregnancy is tolerated well in most of these women with unoperated, or repaired cardiac lesions; however, the risk is increased considerably in certain situations such as pulmonary hypertension, severe valvular stenosis, pulmonary atresia, mechanical prosthetic valves, with Fontan type circulation, in Marfan syndrome and other aortopathy. Counseling prior to pregnancy in CHD also involves discussion of genetic testing, possibility of transmission to the child, management during pregnancy including preimplantation genetic testing, and recommendations regarding fetal echocardiography. All medications including anticoagulation options if needed should be carefully reviewed prior to pregnancy due to maternal and fetal risks. If needed, cardiac surgery or balloon valvuloplasty can be carried out with an increased risk to mother and fetus. Overall, pregnancy in CHD is feasible in most patients with good maternal and fetal outcome. High risk pregnancy patients with CHD have to be counseled by a multidisciplinary team including cardiologists, obstetricians and anesthesiologists at a tertiary care center.

\section{INTRODUCTION}

Congenital heart disease (CHD) is the predominant form of heart disease among pregnant women in developed countries.(I) Since CHD is diagnosed and managed earlier, an increasing number of women with CHD are reaching childbearing age and are considering pregnancy. $\mathrm{CHD}$ does not preclude a successful pregnancy but increases the risk to both mother and child, requiring special management. In patients with repaired complex $\mathrm{CHD}$, some uncertainties still remain about the ability to conceive, the effects of pregnancy on maternal heart disease, and the effects of heart disease on the fetus. The management of patients with complex $\mathrm{CHD}$ during pregnancy requires a collaborative approach between obstetrician, cardiologist and neonatologist to provide the optimal environment for a safe and healthy pregnancy and childbirth. Inheritance of CHD should be discussed and parents should receive appropriate counseling. Fetal or postnatal echocardiography should be performed if indicated.

\section{PREVALENCE OF CHD}

Cardiac malformations constitute a major percentage of significant birth defects, with an estimated prevalence of $0.8 \% .^{(2,3)}$ The true prevalence may be higher, as bicuspid aortic valve is usually excluded from this estimate and occurs in 10 to 20 per 1000 in the general population. ${ }^{(4)}$ Including atrial septal aneurysm and persistent left superior vena cava, each occurring in 5 to 10 per 1000 live births, as well as ventricular septal defects occurring in up to $5 \%$ of newborns, an incidence of $5 \% \mathrm{CHD}$ in live births is an underestimate. ${ }^{(5-9)}$ Dramatic advances in medical care of children with CHD over the past decade have made survival into adulthood a reality, thus increasing the population of adults with CHD by $5 \%$ per year. ${ }^{(10)}$ Thus the number of adults with $\mathrm{CHD}$ has surpassed the number of children with $\mathrm{CHD}$ in developed countries. (I)

\section{GENETIC BASIS OF CHD}

Patients should be counseled about the increased risk of CHD in the fetus. The offspring of women with CHD have a $5 \%$ to $6 \%$ incidence of $\mathrm{CHD}$. In the largest study on pregnancy in $\mathrm{CHD}$, recurrence of $\mathrm{CHD}$ varied between $0.6 \%$ in transposition of the great arteries (TGA) to $8 \%$ in atrioventricular septal defect. ${ }^{(12)}$

The CHD in the offspring is not always the same as in the mother with CHD. In syndromes the incidence of recurrence with each pregnancy may be up to $50 \%$ (e.g. autosomal dominant disorders such as familial atrial septal defect or bicuspid aortic valve). Bicuspid aortic valve is inherited in most patients and occurs in $37-89 \%$ of family members and family screening is recommended. ${ }^{(13,14)}$ In relatives of patients with left ventricular outflow tract lesions, discordant CHD such as abnormalities of the left ventricle and mitral valve frequently occur. ${ }^{(15)}$ In nonsyndromic CHD due to a multifactorial mechanism of inheritance, the cardiac defects in relatives may be different than in the index patient. ${ }^{(16,17)}$

It is important to identify the underlying genetic pattern as there may be involvement of organ systems other than the heart. In addition, it provides prognostic information for outcome, and there may be other 
TABLE 1: Genes associated with CHD (only most common types)

\begin{tabular}{|c|c|c|c|}
\hline & Gene(s) & $\begin{array}{l}\text { Chromosome } \\
\text { location }\end{array}$ & References \\
\hline $\begin{array}{l}\text { Familial CHD } \\
\text { (ASD, AV Block) }\end{array}$ & $N K X 2,5(C S X)$ & $5 q 34-q 35$ & 62.65 \\
\hline D-TGA & PROSIT240 & $12 \mathrm{q} 24$ & 66 \\
\hline Tetralogy of Fallot & $\begin{array}{c}\text { YFPM2/FOG2 } \\
\mathrm{NKX2,5} \\
\text { JAG } 1\end{array}$ & $\begin{array}{c}8 q 23 \\
5 q 34-q 35 \\
20 p 12\end{array}$ & $\begin{array}{l}67 \\
64 \\
68\end{array}$ \\
\hline AV septal defect & CRELDI & $3 p 21$ & 69 \\
\hline Holt-Oram syndrome & TBX5 & $12 q 24$ & 70 \\
\hline Noonan syndrome & $\begin{array}{l}\text { PTPNII } \\
\text { KRAS } \\
\text { SOSI }\end{array}$ & $\begin{array}{c}12 q 24 \\
12 p 1.21 \\
2 p 21\end{array}$ & $\begin{array}{l}71 \\
72\end{array}$ \\
\hline Marfan syndrome & FBNI & $15 q 21.1$ & 73 \\
\hline Marfan-like syndrome & TGFBR2 & $3 p 22$ & 74 \\
\hline $\begin{array}{l}\text { Cardio-fascio-cutaneous } \\
\text { syndrome }\end{array}$ & $\begin{array}{l}\text { KRAS } \\
\text { BRAF } \\
\text { MEKI } \\
\text { MEK2 }\end{array}$ & $\begin{array}{c}12 p 12.1 \\
7 q 34 \\
15 q 21 \\
7 q 32\end{array}$ & $\begin{array}{l}75 \\
75 \\
76 \\
76 \\
\end{array}$ \\
\hline LEOPARD syndrome & PTPNII & $12 q 24$ & 77 \\
\hline
\end{tabular}

Table I modified after Pierpont et al.(11)

family members for whom genetic testing is appropriate. (II) Some of the genetic defects known in CHD are shown in Table I.

There are various genetic tests that can assist the physician in diagnosing genetic alterations in a patient with $\mathrm{CHD}$ including cytogenetic techniques, fluorescence in situ hybridization (FISH), and DNA mutation analysis. ${ }^{(I I)}$ Chromosome analysis may reveal chromosomal aberration in $8-13 \%$ of neonates with $\mathrm{CHD}$. ${ }^{(18)}$ Common genetic defects include: $22 q 1 /$ deletion, microdeletion $7 q \mid 1.23$, or deletions 20p I2. Genetic testing may determine a mechanism of disease and provides an important basis for genetic counseling. Preimplantation genetic testing is another available option for patients with CHD, undergoing certain methods of assisted reproduction.

\section{PHYSIOLOGIC HEMODYNAMIC CHANGES DURING PREGNANCY, DELIVERY AND POSTPARTUM}

Due to hormonal changes that relax smooth muscle followed by formation of the placenta and fetal circulation, the blood volume increases during pregnancy from the fifth week into the third trimester. There is an up to $50 \%$ increase in circulating blood volume. ${ }^{(19)}$ During pregnancy, there is a reduction in systemic and pulmonary vascular resistance and a slight decrease in blood pressure. The heart rate increases about 10-20 beats per minute. These hemodynamic changes result in a steady increase in cardiac output during pregnancy until the 32nd week, at which time cardiac output and oxygen consumption plateau at $30-50 \%$ above the prepregnancy level.

At the time of delivery, cardiac output increases as much as $80 \%$ above the prepregnancy level and may be as great as $9 \mathrm{~L} / \mathrm{min}$. Approximately $500 \mathrm{~mL}$ of blood is lost at the time of vaginal delivery, and approximately I $000 \mathrm{~mL}$ during a normal caesarean delivery. ${ }^{(20,21)}$
Normally, the hemodynamic changes that occur during pregnancy are well tolerated by the mother. However, CHD may be initially identified during pregnancy because of increased cardiac output or because minor preexisting symptoms may be exacerbated.

\section{TIME AND ROUTE OF DELIVERY}

The time and route of delivery and optimal anesthesia and analgesia should be planned before the onset of spontaneous labor to facilitate the delivery and to intervene as appropriate. With few exceptions, vaginal delivery is preferred for women with CHD. For attempted vaginal delivery, epidural anaesthesia to obtund the sympathetic response is a key aspect of management. Instrumentation (forceps or vacuum extraction) should only be used if necessary. Caesarean delivery is indicated for obstetric reasons and for patients with preterm labor while anticoagulated with warfarin. The fetus remains anticoagulated despite reversing the warfarin effect in the mother, and therefore is at risk of fetal intracranial hemorrhage. Caesarean delivery should also be considered for patients with fixed cardiac obstructive lesions, patients with unstable aortic lesions at risk of dissection and for patients with deteriorating functional status. Most would also suggest that patients with pulmonary hypertension be considered for cesarean delivery. Most of these patients should be managed in a tertiary care center.

\section{PRINCIPLES OF MANAGEMENT OF PREGNANCY IN WOMEN WITH CHD}

Women with CHD should undergo a detailed assessment of any cardiac abnormality to determine the maternal and fetal risks of pregnancy antepartum. The safety of the mother is the highest priority.

Fetal growth and development are monitored with ultrasonography. Fetal cardiac ultrasonography is recommended in women with $\mathrm{CHD}$ between the 18 th to 20th week to screen for congenital cardiac lesions. Some cardiac anomalies can be diagnosed with a first trimester II to 14 week, or 14 to 16 week scan. ${ }^{(22)}$

The management of pregnant women with CHD in NYHA class I or II should include limiting strenuous exercise, having adequate sleep and rest, maintaining a low-salt diet, avoiding anemia (keep hemoglobin > l Ig), having frequent obstetrical and cardiovascular prenatal examinations and monitoring for arrhythmias.

The option to continue or interrupt the pregnancy in high risk patients should be discussed with the patient. If the pregnancy is continued, frequent rest is often required during part of the pregnancy with close cardiac and obstetric monitoring and prophylaxis for thromboembolism. Treatment of congestive heart failure is more challenging in pregnant than in nonpregnant women. Conservative measures are very important; however, pharmacologic therapy may be required, and medical options are limited due to adverse effects on the fetus. Maternal postpartum care should include early ambulation, attention to neonatal concerns, counseling with regard to breast feeding and consideration of contraception as appropriate. 


\section{OUTCOME OF PREGNANCY IN CHD}

The pregnancy risk in CHD is dependent on: I) the underlying cardiac defect, whether unoperated, palliated or repaired, 2) the use of chronic medication, 3) the presence of cyanosis, pulmonary hypertension or intracardiac shunts, 4) function of the subpulmonary ventricle, and 5) the functional class. Due to the previously described hemodynamic changes during pregnancy, the outcome of pregnancy is affected by the presence of $\mathrm{CHD}$ and has recently been summarized in a large review by Drenthen et al. (12) including 2 491 pregnancies in women with different types of CHD. Cardiovascular events, rarely seen in the healthy general population, were documented in $11 \%$ of completed pregnancies. ${ }^{(12)}$ Obstetric complications were not more prevalent than in the normal population apart from hypertensive and thromboembolic disorders. Pregnancy outcome was affected with a high offspring mortality rate ( $4 \%$ versus $<1 \%$ in the general population) and a spontaneous miscarriage rate of 15\%. Mortality and cardiovascular events were highest in mothers with Eisenmenger syndrome. Of note, endocarditis was most often observed in atrial septal defect; an explanation is lacking.

Arrhythmias occurred in $>10 \%$ of pregnant women with atrioventricular (AV) septal defect, transposition of the great arteries (TGA) and after Fontan palliation. ${ }^{(12)}$ Supraventricular arrhythmias are most common in patients with TGA, Fontan, and AV septal defects. Heart failure is especially common in TGA, cyanotic heart disease, pulmonary atresia with VSD, and Eisenmenger syndrome (occurring in $21 \%$ ). Hypertensive disorders are more common in aortic stenosis, pulmonary stenosis, aortic coarctation and TGA. Spontaneous preterm delivery is more common in more complex CHD including Ebstein, TGA, pulmonary valve atresia with VSD, Fontan, cyanotic CHD, and Eisenmenger, with preterm delivery rates between $22 \%$ and $65 \%{ }^{\left({ }^{(12)}\right.}$ Miscarriages are much more frequent than elective abortions in most CHD patients. However, after Fontan repair and in patients with pulmonary atresia with ventricular septal defects, the number of elective abortions is considerably higher than in other $\mathrm{CHD}$ patients (12\% versus $5 \%$ ).

Maternal prognosis during pregnancy is strongly related to functional class. Siu and colleagues reported New York Heart Association (NYHA) functional class $>2$ to be the strongest predictor of cardiovascular complication during pregnancy. ${ }^{(23)}$ Additional factors that contribute to the risk of a cardiovascular complications during pregnancy include: a prior history of heart failure, transient ischemic attack, stroke or arrhythmia, the presence of cyanosis, left heart obstruction with either mitral stenosis with a mitral valve area $<2 \mathrm{~cm}^{2}$, or aortic stenosis with a peak left ventricular outflow tract gradient $>30 \mathrm{mmHg}$ and aortic valve area $<1.5 \mathrm{~cm}^{2}$ by echocardiographic Doppler examination. Another study reported an increased cardiac and neonatal complication rate in women with $\mathrm{CHD}$ and impaired subpulmonary ventricular systolic function, severe pulmonary regurgitation, or a smoking history. ${ }^{(24)}$
Pregnancy risk classification of various lesions in CHD is shown in Table II. The risk factors that predict outcome include: I) poor functional class, 2) systemic ventricular ejection fraction $<40 \%$ 3) preconception history of arrhythmia, stroke transient ischemic attack, and pulmonary edema, or 4) left heart obstruction. The expected cardiac event rate ranges from $5,27-75 \%$ with 0,1 or $>$ I risk factors. ${ }^{(3)}$

In contrast to fixed obstructive cardiac lesions or those associated with pulmonary hypertension, shunts or regurgitant lesions are generally relatively well tolerated because of the pregnancy-related decrease in systemic vascular resistance. ${ }^{25-27)}$ Mitral valve prolapse is no contraindication for pregnancy.(27)

Medium or high-risk pregnancy includes women with I) prosthetic valves; 2) obstructive lesions, including uncorrected coarctation of the aorta; 3) Marfan syndrome or other aortic disorders; 4) cyanotic CHD; 5) pulmonary hypertension; 6) systemic ventricular dysfunction (ejection fraction $<40 \%$ ), or 7) significant uncorrected CHD (see Table II).

TABLE 2: Pregnancy risk classification of various lesions of CHD

\begin{tabular}{|c|c|c|}
\hline Type of Risk & Type of Lesion & Main caveats \\
\hline \multirow[t]{5}{*}{ Low Risk } & $\begin{array}{l}\text { Unrepaired/residual atrial or } \\
\text { ventricular septal defect, no PHT }\end{array}$ & Endocarditis, paradoxical emboli \\
\hline & $\begin{array}{l}\text { Unrepaired/residual patent ductus } \\
\text { arteriosus, no PHT }\end{array}$ & Heart failure \\
\hline & $\begin{array}{l}\text { Unrepaired regurgitant valvular } \\
\text { heart disease, NYHA I/II }\end{array}$ & Arrhythmias, heart failure \\
\hline & Repaired Tetralogy of Fallot & Arrhythmias, RV failure \\
\hline & $\begin{array}{l}\text { Repaired left or right ventricular } \\
\text { outflow tract stenosis/coarctation }\end{array}$ & $\begin{array}{l}\text { Pre-eclampsia, heart failure, } \\
\text { arrhythmias }\end{array}$ \\
\hline \multirow[t]{7}{*}{ Moderate Risk } & $\begin{array}{l}\text { Unrepaired regurgitant, valvular } \\
\text { heart disease, NYHA III/IV }\end{array}$ & Heart failure, arrhythmias \\
\hline & Unrepaired/residual mitral stenosis & Pulmonary edema, atrial fibrillation \\
\hline & $\begin{array}{l}\text { Aortic and/or mitral valve disease } \\
\text { with severe left ventricular } \\
\text { dysfunction, EF }<40 \%\end{array}$ & Heart failure, arrhythmias \\
\hline & $\begin{array}{l}\text { Unrepaired/residual left or right } \\
\text { ventricular outflow tract stenosis/ } \\
\text { coarctation }\end{array}$ & $\begin{array}{l}\text { Hemorrhage, thromboembolic } \\
\text { events, heart failure }\end{array}$ \\
\hline & Cyanotic lesions without PHT & $\begin{array}{l}\text { Systemic right ventricular failure, } \\
\text { arrhythmias }\end{array}$ \\
\hline & $\begin{array}{l}\text { Systemic right ventricle (TGA after } \\
\text { atrial switch, CCTGA) }\end{array}$ & $\begin{array}{l}\text { Heart failure, thromboembolic } \\
\text { complications, arrhythmias }\end{array}$ \\
\hline & $\begin{array}{l}\text { Fontan-type circulation } \\
\text { Ebstein's anomaly }\end{array}$ & \\
\hline \multirow[t]{3}{*}{ High Risk } & Mechanical heart valves & Valve thrombosis \\
\hline & $\begin{array}{l}\text { Marfan syndrome, aortic root } \\
>4 \mathrm{~cm}\end{array}$ & Aortic dissection \\
\hline & $\begin{array}{l}\text { Eisenmenger syndrome, other } \\
\text { pulmonary arterial hypertension }\end{array}$ & $\begin{array}{l}\text { I I-50\% risk of maternal death, } \\
\text { arrythmias, heart failure }\end{array}$ \\
\hline \multicolumn{3}{|c|}{$\begin{array}{l}\text { PHT = pulmonary hypertension; NYHA = New York Heart Association; EF = ejection fractio } \\
T G A=\text { transposition of the great arteries; CCTGA = congenitally corrected transposition of the gre } \\
\text { arteries; fib = fibrillation } \\
\text { Modified after Uebing et al.(3) and Bonow at al. } .^{(27)}\end{array}$} \\
\hline
\end{tabular}




\section{CARDIAC CONTRAINDICATIONS TO PREGNANCY}

There are certain cardiac conditions in which pregnancy should be avoided, and if pregnancy occurs, termination should be considered. These include severe pulmonary hypertension (pulmonary artery pressure $\geq 3 / 4$ systemic pressure) related to Eisenmenger syndrome or another cause; cardiomyopathy with class III or IV congestive heart failure or left ventricular dysfunction (ejection fraction $<40 \%$ ) and any form of severe obstructive cardiac lesion such as aortic stenosis, mitral stenosis, pulmonary stenosis, or coarctation; they may result in important morbidity and sometimes mortality during pregnancy. Intervention before pregnancy is the preferred management option if possible. Women with Marfan syndrome and an aortic root $\geq 40 \mathrm{~mm}$ should be strongly counseled to avoid pregnancy, because of the unpredictable risk of aortic dissection and rupture during pregnancy or postpartum. ${ }^{(18)}$ Severe cyanosis is a relative contraindication to pregnancy, primarily because of adverse fetal outcome.

\section{MANAGEMENT OF PREGNANCY IN SELECT PATIENT GROUPS}

Outcome of Pregnancy in Marfan Syndrome and other Aortopathies

In Marfan syndrome, an autosomal dominant inherited connective tissue disorder, pregnancy increases the risk of aortic dissection. On top of underlying inherited changes of the aortic media, the aorta is further affected by superimposed hormonal and hemodynamic changes during pregnancy. Relaxin, an insulin-like growth factor, is secreted during pregnancy. ${ }^{(28)}$ This results in an unpredictable maternal risk of aortic dissection and rupture. Patients with Marfan syndrome who have an aortic dimension over $40 \mathrm{~mm}$ should be counseled against pregnancy without aortic surgery due to the unpredictable risk of a cardiovascular event.According to the Canadian guidelines, ${ }^{(29)}$ pregnancy is relatively safe in women with Marfan syndrome with an aortic root diameter less than $45 \mathrm{~mm}$, and no significant aortic and mitral regurgitation. However, there is a $1 \%$ risk of aortic dissection, endocarditis or congestive heart failure during pregnancy. ${ }^{(30)}$ Cardiovascular complications were reported in 61 women with Marfan syndrome; only one type B aortic dissection occurred in a patient with previous type $A$ dissection. ${ }^{(31)}$ No aortic dissection occurred in women with an aortic root diameter of less than $46 \mathrm{~mm} .{ }^{(31)}$

If pregnancy is being considered in a patient with Marfan syndrome, careful prepregnancy cardiovascular evaluation and counseling is recommended. Genetic counseling is also vital prior to pregnancy and should include a discussion about the risk of inheritance of Marfan syndrome (which is 50\% per pregnancy), the variability of the disorder and the possibility of prenatal diagnosis. Once pregnant, patients with the Marfan syndrome should be followed closely with regular aortic imaging by echocardiography. Treatment with a beta-blocker during pregnancy is recommended. Fetal heart ultrasonography should be performed to assess the aorta and cardiac status of the fetus. Rare cases of severe Marfan syndrome may be diagnosed in the fetus. Near term, a facilitated delivery should be planned to avoid excessive strain on the aorta. If the aorta is over $40 \mathrm{~mm}$, or has enlarged during pregnancy, caesarean delivery should be considered. The postpartum period requires special monitoring. The risk of aortic dissection persists during this time and there is also an increased risk of postpartum hemorrhage.

Patients with bicuspid aortic valves and coarctation of the aorta associated with aortopathy as well as other aortopathies have a predisposition for aortic dissection and aneurysm formation, and this risk may be increased during pregnancy. Prepregnancy aortic assessment is imperative in these patients. Once pregnancy occurs beta-blockers may decrease the rate of dilatation of the aortic root and may be considered in all pregnant patients with aortopathy, although there are no data that demonstrate that beta-blocker therapy is beneficial in this population. Regular aortic follow-up using echocardiography is recommended during pregnancy and shortly after birth in patients with aortopathy.

\section{Outcome of Pregnancy in Left Ventricular Outflow Tract Obstruction}

The two most common causes of left ventricular outflow tract obstruction include aortic stenosis and coarctation of the aorta. A fixed outflow tract resistance may not accommodate the increased cardiac output in pregnancy and increases the risk of heart failure. Mild left ventricular outflow tract obstruction is usually tolerated well.

There are not many data on outcome of severe aortic stenosis in pregnancy. An initial review published in 1993 showed a maternal mortality of I I\% among 65 women with aortic stenosis. ${ }^{(32)}$ In a more recent study involving 35 women having 58 pregnancies, the outcome was more optimistic. ${ }^{(33)}$ Hypertension related disorders occurred in $11 \%$, cardiac failure in $4 \%$, and atrial arrhythmias in 6\%. ${ }^{(33)}$ Overall, an increase in obstetric and perinatal complications occurred. However, pregnancy is tolerated well in most women with congenital aortic stenosis. The outcome and management for supravalvular and subvalvular aortic stenosis does not differ significantly from valvular aortic stenosis. The effect of pregnancy on a patient with valve disease depends on the specific valve lesion, ventricular function, pulmonary artery pressure, and on the New York Heart Association (NYHA) functional class. A careful cardiovascular evaluation should be performed prior to pregnancy in patients with valvular heart disease with a careful follow-up during pregnancy.

Interventional procedures are effective alternatives to surgery in several cardiac disorders that occur during pregnancy. Preliminary reports are optimistic; however, no large series have reported on the safety of cardiac interventions during pregnancy. Percutaneous balloon aortic valvuloplasty has been reported as a safe and effective palliative procedure during pregnancy. ${ }^{(34-37)}$ These procedures should be considered alternatives to surgery in patients with severe symptomatic native-valve stenosis identified during pregnancy. 
Cardiac surgery should be reserved for patients refractory to medical management in whom further delay would prove detrimental to maternal and fetal health. ${ }^{(38)}$ Cardiopulmonary bypass can adversely affect both the mother and fetus. High-flow, high-pressure, normothermic perfusion appears safest from a fetal standpoint. Fetal heart rate monitoring is recommended during cardiopulmonary bypass. When cardiac surgery is necessary during pregnancy, the optimal time is between the 24th and 28th week of pregnancy and the duration of cardiopulmonary bypass should be kept as short as possible. Fetal death around the time of cardiac surgery is reported to be approximately 15\%.

Coarctation of the thoracic aorta occurs in approximately $9 \%$ of pregnant women with $\mathrm{CHD}$. The outcome of pregnancy in 50 women with coarctation was reported by Beauchesne et al. ${ }^{(39)} 30$ patients had coarctation repair before pregnancy, 10 had repair after pregnancy, 4 had repair before and after pregnancy, and 6 had no history of repair. The 50 women had 118 pregnancies resulting in 106 births. $4 \%$ of the offspring had CHD. 38\% had a gradient of $\geq 20 \mathrm{mmHg}$ across the coarctation site during pregnancy. 30\% had hypertension during pregnancy, II of whom (83\%) had hemodynamically significant coarctation during that time. A patient with Turner syndrome died of a Stanford type A dissection at 36 weeks of pregnancy. This review suggests that hemodynamically important coarctation should be repaired prior to pregnancy, and all patients with coarctation should undergo careful prepregnancy evaluation, including an assessment of the region of coarctation repair and the ascending aorta. Another study described the outcome of pregnancy in 54 women after coarctation repair that had 126 pregnancies resulting in 98 successful births. Overall, there was an excess of miscarriages and hypertensive disorders of pregnancy. ${ }^{(40)}$ Coarctation is the only CHD known to be an independent predictor of pre-eclampsia.

\section{Outcome of Pregnancy in Tetralogy of Fallot}

Tetralogy of Fallot (TOF) represents 5-6\% of CHD and includes anterior and superior infundibular septal displacement with ventricular septal defect, aortic override, infundibular obstruction, and right ventricular hypertrophy. Pregnancy is not advised in patients with unrepaired tetralogy of Fallot. After repair of tetralogy of Fallot, prognosis for a successful pregnancy is good unless there are important hemodynamic residua or functional capacity is reduced. The most common problems after TOF repair include pulmonary regurgitation or persistent outflow obstruction, tricuspid regurgitation, and right ventricular dysfunction. ${ }^{(3)}$ Pregnancy is usually well tolerated even in the setting of severe pulmonary regurgitation, as long as the right ventricular function is no more than mildly depressed and sinus rhythm is maintained. ${ }^{(41)}$ The risk of fetal loss is increased, and $6 \%$ of the offspring has congenital anomalies, ${ }^{(41)}$ especially in the setting of a $22 \mathrm{q} 11.2$ microdeletion. Screening from $22 \mathrm{q} \mid 1.2$ microdeletion should be considered in patients with conotruncal abnormalities prior to pregnancy in order to provide appropriate genetic counseling. ${ }^{(42)}$ In the absence of $22 \mathrm{q}$ I I deletion, the risk of a fetus having CHD is approximately 4-6\%. Fetal echocardiography should be offered to the mother in the second trimester.
A comprehensive informed cardiovascular evaluation is recommended prior to each pregnancy.

\section{Outcome of Pregnancy in Eisenmenger Syndrome or other} causes of severe pulmonary hypertension and cyanosis

Severe pulmonary vascular disease has long been known to carry the highest risk, with maternal mortality of $12-50 \%{ }^{(43-45)}$ regardless of the cause. The fall in peripheral vascular resistance during pregnancy increases the right-to-left shunt and exaggerates cyanosis. Hypovolemia thromboembolic events, and pre-eclampsia are particularly hazardous Both vaginal and caesarean deliveries are associated with a high maternal death rate. In primary pulmonary hypertension (mortality $30 \%$ ) and Eisenmenger syndrome (36\%), maternal mortality was comparable and better than in secondary vascular pulmonary hypertension (56\%) in a study involving 125 patients. ${ }^{(46)}$ In a more recent study, 3 stable patients on prostacyclin therapy and lowmolecular-weight heparin were able to successfully complete pregnancy. ${ }^{(47)}$

Pregnant cyanotic women have a high risk of fetal loss. Also, cyanosis is a recognized handicap to fetal growth, resulting in low birth weight infants.

Cyanosis is rare in women with $\mathrm{CHD}$ but associated with an increased pregnancy risk as shown in a prospective multicenter study. ${ }^{(23)}$ Cyanotic women have an increased risk for neonatal and maternal cardiac complications. Due to known hemostatic defects, the odds ratio for postpartum hemorrhage was 27 (4-177) in cyanotic women (oxygen saturation <90\%). ${ }^{(23)}$

\section{PREGNANCY IN SURVIVORS OF CHD SURGERY}

Pregnant survivors of $\mathrm{CHD}$ surgery are increasingly encountered by obstetricians and often manifest unique problems during pregnancy. Patients with simple corrected lesions such as atrial septal defects may be at risk of arrhythmias during pregnancy and prepregnancy assessment is warrented. Patients with more complex repaired CHD may offer special problems due to residual lesions, prosthetic heart valves, an increased incidence of arrhythmias, a limited ability to increase cardiac output and an increased risk of pre-eclampsia or pregnancy related hypertension. The seemingly good health of a woman after CHD repair can deteriorate with pregnancy; thus, careful evaluation and consideration of possible complications should be performed prior to pregnancy. These patients are also at risk of increased obstetric (premature rupture of membranes, premature labor, postpartum hemorrhage, etc.) and neonatal complications (small for gestational age children, premature delivery). Multidisciplinary care is mandatory in these patients.

In women with prior atrial repair of complete TGA (Senning or Mustard repair), there is a high incidence of maternal cardiovascular complications such as arrhythmias and heart failure. There is also an increased risk of 
obstetric complications (premature labor and rupture of membranes), a high fetal and neonatal mortality rate (1 1.8\%) and a high incidence of pre-eclampsia and pregnancy-induced hypertension. ${ }^{(48,49)}$

Women following Fontan palliation have a higher infertility rate than other patients with CHD and they experience an increased risk of arrhythmias and miscarriage with pregnancy. ${ }^{(50)}$

\section{PREGNANCY IN PATIENTS WITH PROSTHETIC HEART VALVES}

The best type of heart valve prosthesis to use in women of childbearing age who have critical valvular heart disease is controversial.(27) Some data have suggested that premature valve deterioration occurs in bioprosthetic valves during pregnancy, ${ }^{(51)}$ but this has not been documented conclusively or demonstrated experimentally. It has been suggested that reoperation (required for most patients with bioprosthetic valves) carries a higher risk of morbidity and mortality than the risk of anticoagulation during pregnancy. However, more recent surgical data would suggest that the risk of reoperation may not be substantially higher than the risk of the initial operation, depending on patient characteristics and surgical experience. The Ross procedure in young women requiring aortic valve replacement prior to pregnancy is an option; ${ }^{(52.53)}$ however, institutions must have enough expertise in this difficult operation.

Pregnant women with a mechanical heart valve have an increased risk for developing prosthetic valve thrombosis or other life-threatening complications during pregnancy. The complication rate depends on the anticoagulation regimen used during pregnancy. The best management for a pregnant woman who requires anticoagulation is controversial (see section on Anticoagulation in Pregnancy).

\section{CARDIOVASCULAR DRUGS IN PREGNANCY}

Drugs should be avoided whenever possible. Most cardiovascular drugs cross the placenta and are secreted in breast milk. The risk-to-benefit ratio must be considered when administering any medications during pregnancy. ${ }^{(27)}$ The following cardiovascular drugs are considered to be relatively safe during pregnancy (see comments below); these include digoxin, diuretics, select beta-blockers, calcium channel blockers, low dose aspirin, and intravenous low dose adenosine.(27) Not absolutely contraindicated are also other medications including amiodarone, flecainide, lidocaine, procainamide, propafenone and sotalol, which should be used with caution and can have considerable side effects. ${ }^{(27)}$

Medications that cause concern when administered during pregnancy include warfarin (skeletal defects, abnormalities of central nervous system), amiodarone (hypothyroidism, potential brain damage, intrauterine growth retardation, bradycardia and QT prolongation in the newborn), phenytoin (heart defects, orofacial abnormalities) and spironolactone (anomalies external genitalia). The use of angiotensin converting enzyme (ACE) inhibitors and angiotensin II receptor blockers is contraindicated during pregnancy. Maternal-fetal transfer of captopril has been documented and, in animals, exposure to ACE inhibitors during pregnancy has produced prolonged fetal hypotension and death. In addition, use of ACE inhibitors during pregnancy increases the risk of early delivery, low birth weight, Oligohydramnion, or neonatal anuria and renal failure (or some combination of these) and an increased risk of cardiovascular and central nervous system malformations. ${ }^{(54)}$ However, these agents can be safely used during lactation.

Select beta-blockers (acebutolol, metoprolol, propranolol, labetalol) are thought to be relatively safe and may be used in the treatment of arrhythmias, hypertrophic cardiomyopathy, and hyperthyroidism during pregnancy if clinically indicated. (27) However, all available beta-blockers cross the placenta and are present in human breast milk. ${ }^{(5)}$ These agents can reach significant levels in the fetus or newborn. Therefore, if used during pregnancy, it is appropriate to monitor fetal and newborn heart rate as well as blood glucose and respiratory status after delivery. In pregnancies complicated by hypertension, adverse fetal effects have been associated with the use of atenolol, especially when atenolol was used in the first trimester of pregnancy: then it was associated with low birth weight independent of pre-eclampsia. ${ }^{(56)}$ There was a trend for early delivery and low birth weight, especially when atenolol was administered early in pregnancy. Additionally, some consider atenolol unsafe during breastfeeding as it may concentrate in breast milk, resulting in pharmacologically significant dose to the breastfed infant with an increased risk for cyanosis, hypotension and bradycardia described in one case. ${ }^{(55)}$ Safer alternatives such as acebutolol, propranolol or metoprolol should be used.

\section{MANAGEMENT OF ARRHYTHMIAS DURING PREGNANCY}

Cardiac arrhythmias during pregnancy should be evaluated the same as in a non-pregnant patient and the underlying disease or precipitating factors treated if possible.

Direct current cardioversion may be used and is the treatment of choice for arrhythmias causing hemodynamic compromise during pregnancy. For less urgent situations, pharmacologic management of arrhythmias may be required. Intravenous adenosine is the treatment of choice for supraventricular arrhythmias.

\section{ANTICOAGULATION DURING PREGNANCY}

The risk of thromboembolism is increased $6 x$ during pregnancy and $1 \mathrm{Ix}$ in the puerperium. Warfarin crosses the placenta and carries major risks for the fetus. ${ }^{(57,58)}$ When warfarin is given throughout pregnancy in a patient with mechanical valve prosthesis, the risk of embryopathy is $6.4 \%$, the risk of spontaneous abortion $25 \%$ and thromboembolic 
complications in 3.9\%. Warfarin may be the safest form of anticoagulation for the mother.

Unfractionated heparin does not cross the placenta and is thus safer for the fetus but it does not provide adequate anticoagulation coverage for the mother. Low molecular weight heparins are an alternative, but data supporting safe use in pregnancy for women with mechanical valve prostheses are lacking. ${ }^{(57-59)}$ There are limited data on the efficacy of low molecular weight heparin use during pregnancy in patients with mechanical valve prosthesis.

Labor and delivery is a particularly high-risk time for patients who require anticoagulation during pregnancy. Patients who are fully anticoagulated with warfarin are admitted around 36 weeks gestation and placed on full intravenous heparinization, allowing at least 4-5 days for warfarin to "wash-out" from the fetus. Delivery is planned and heparin is held 4-6 hours before the delivery. Caesarean delivery should be performed if unplanned labor occurs during warfarin anticoagulation because of the risk of fetal intracranial hemorrhage with vaginal delivery. Heparin should be resumed four to six hours after caesarean or vaginal delivery in the absence of bleeding.

The European Society of Cardiology suggests continuation of warfarin anticoagulation during pregnancy and the American College of Chest Physicians recommend avoiding warfarin and using aggressive dose adjusted LMWH or unfractionated heparin during pregnancy. ${ }^{(60)}$ Addition of low-dose aspirin for the high-risk patient was also suggested. Thus, there is no consensus on the best anticoagulation regimen during pregnancy for patients with mechanical valve prostheses. An informed discussion with the patient and her partner, and meticulous monitoring of the chosen anticoagulation regimen is mandatory.

\section{ENDOCARDITIS PROPHYLAXIS}

The American Heart Association does not recommend endocarditis prophylaxis for patients having caesarean or vaginal delivery. ${ }^{(61)}$

Our recommendations are more conservative. We recommend the intravenous administration of antibiotics for endocarditis prophylaxis using the gastrointestinal or genitourinary regimen in high-risk cardiac patients because of the risk of undiagnosed infections and the significant patient morbidity and mortality should infective endocarditis occur. Antibiotic therapy should be administered 30 to 60 minutes before delivery is expected and repeated 8 hours later.

\section{CONCLUSIONS}

As more women with $\mathrm{CHD}$ are reaching child-bearing age, and are considering pregnancy or becoming pregnant, detailed knowledge about possible complications and problems is mandatory. Pregnancy in CHD is feasible in most patients with good maternal and fetal outcome. High risk pregnancy patients with CHD have to be counseled by a multidisciplinary team including cardiologists, obstetricians, anaesthesists, and occasionally geneticists at a tertiary care center.

\section{REFERENCES:}

I. Pitkin RM, Perloff JK, Koos B], Beall MH. Pregnancy and congenital heart disease. Ann Intern Med. 1990; 1 1 2:445-54.

2. Hoffman Jl. Congenital heart disease: incidence and inheritance. Pediatr Clin North Am. 1990;37:25-43.

3. Uebing A, Steer PJ, Yentis SM, Gatzoulis MA. Pregnancy and congenital heart disease. BMJ. 2006;332:40I-6.

4. Ward C. Clinical significance of the bicuspid aortic valve. Heart. 2000;83:8I-5.

5. Benson DW, Sharkey A, Fatkin D, Lang P, Basson CT, McDonough B, Strauss AW, Seidman JG, Seidman CE. Reduced penetrance, variable expressivity, and genetic heterogeneity of familial atrial septal defects. Circulation. 1998;97:2043-8.

6. Roguin N, Du ZD, Barak M, Nasser N, Hershkowitz S, Milgram E. High prevalence of muscular ventricular septal defect in neonates. J Am Coll Cardiol. 1995;26: I545-8.

7. Du ZD, Roguin N, Barak M, Bihari SG, Ben-Elisha M. High prevalence of muscular ventricular septal defect in preterm neonates. Am | Cardiol. 1996;78: I | 83-5.

8. Hoffman JI, Kaplan S. The incidence of congenital heart disease. J Am Coll Cardiol. 2002:39:1 1890-900

9. Hoffman JI, Kaplan S, Liberthson RR. Prevalence of congenital heart disease. Am Heart J. 2004; |47:425-39.

10. Brickner ME, Hillis LD, Lange RA. Congenital heart disease in adults. First of two parts. N Engl J Med. 2000;342:256-63.

II. Pierpont ME, Basson CT, Benson DW, Ir., Gelb BD, Giglia TM, Goldmuntz E, McGee G, Sable CA, Srivastava D, Webb CL. Genetic basis for congenital heart defects: current knowledge: a scientific statement from the American Heart Association Congenital Cardiac Defects Committee, Council on Cardiovascular Disease in the Young: endorsed by the American Academy of Pediatrics. Circulation. 2007; I 15:30 I 5-38.

12. Drenthen W, Pieper PG, Roos-Hesselink JW, van Lottum WA, Voors AA, Mulder BJ, van Dijk AP, Vliegen HW, Yap SC, Moons P, Ebels T, van Veldhuisen DJ. Outcome of pregnancy in women with congenital heart disease: a literature review. I Am Coll Cardiol. 2007:49:2303-II.

13. Aboulhosn J, Child JS. Left ventricular outflow obstruction: subaortic stenosis, bicuspid aortic valve, supravalvar aortic stenosis, and coarctation of the aorta. Circulation. 2006; 1 14:2412-22

14. Cripe L,Andelfinger G, Martin LJ, Shooner K, Benson DW. Bicuspid aortic valve is heritable. J Am Coll Cardiol. 2004;44:I 38-43.

15. Lewin MB, McBride KL, Pignatelli R, Fernbach S, Combes A, Menesses A, Lam W, Bezold LI, Kaplan N,Towbin JA, Belmont JW. Echocardiographic evaluation of asymptomatic parental and sibling cardiovascular anomalies associated with congenital left ventricular outflow tract lesions. Pediatrics. 2004:1| 4:69|-6.

16. Digilio MC, Casey B, Toscano A, Calabro R, Pacileo G, Marasini M, Banaudi E, Giannotti A Dallapiccola B, Marino B. Complete transposition of the great arteries: patterns of congenital heart disease in familial precurrence. Circulation. 200 I; 104:2809- 14.

17. Calcagni G, Digilio MC, Sarkozy A, Dallapiccola B, Marino B. Familial recurrence of congenital heart disease: an overview and review of the literature. Eur J Pediatr. 2007; $166: 111-6$

18. Ferencz C,Neill CA, Boughman JA, Rubin JD, Brenner JI,Perry LW. Congenital cardiovascular malformations associated with chromosome abnormalities: an epidemiologic study. J Pediatr. | 989; | | 4:79-86.

19. Gleicher N. Elkayam U. Principles and Practice of Medical Therapy in Pregnancy. 1992; Edn 2.

20. Clapp JF, 3rd, Capeless E. Cardiovascular function before, during, and after the first and subsequent pregnancies. Am J Cardiol. 1997;80:1 469-73.

21. Hunter S, Robson SC. Adaptation of the maternal heart in pregnancy. Br Heart 1992;68:540-3.

22. Weiner Z, Goldstein I, Bombard A, Applewhite L, Itzkovits-Eldor J. Screening for structura fetal anomalies during the nuchal translucency ultrasound examination. Am | Obstet Gynecol. 2007:197:181 el-5.

23. Siu SC, Sermer M, Colman JM, Alvarez AN, Mercier LA, Morton BC, Kells CM, Bergin ML Kiess MC, Marcotte F, Taylor DA, Gordon EP, Spears JC, Tam JW, Amankwah KS, Smallhorn JF, Farine D, Sorensen S. Prospective multicenter study of pregnancy outcomes in women with heart disease. Circulation. 200 I: 104:515-21.

24. Khairy P, Ouyang DW, Fernandes SM, Lee-Parritz A, Economy KE, Landzberg MJ. Pregnancy outcomes in women with congenital heart disease. Circulation. 2006; I | 3:5 I 7-24.

25. Zuber M, Gautschi N, Oechslin E, WidmerV, KiowskiW, Jenni R. Outcome of pregnancy in women with congenital shunt lesions. Heart. 1999;81:271-5.

26. Hameed A, Karaalp IS, Tummala PP, Wani OR, Canetti M, Akhter MW, Goodwin Zapadinsky N, Elkayam U. The effect of valvular heart disease on maternal and fetal outcome of pregnancy. J Am Coll Cardiol. 200 I;37:893-9.

27. Bonow RO, Carabello BA, Kanu C, de Leon AC, Jr., Faxon DP, Freed MD, Gaasch WH, Lytle BW, Nishimura RA, O'Gara PT, O'Rourke RA, Otto CM, Shah PM, Shanewise JS, Smith SC, Ir.Jacobs AK,Adams CD,Anderson JL,Antman EM, Faxon DP, FusterV, Halperin JL, Hiratzka LF, Hunt SA, Lytle BW, Nishimura R, Page RL, Riegel B. ACC/AHA 2006 guidelines for the management of patients with valvular heart disease: a report of the American College of Cardiolooy/American Heart Association Task Force on Practice Guidelines (writin committee to revise the 1998 Guidelines for the Management of Patients With Valvular Heart Disease): developed in collaboration with the Society of Cardiovascular Anesthesiologists: endorsed by the Society for Cardiovascular Angiography and Interventions and the Society of Thoracic Surgeons. Circulation. 2006; I | 4:e84-23|. 
28. Bryant-Greenwood GD, Schwabe C. Human relaxins: chemistry and biology. Endocr Rev. 1994; 15:5-26.

29. Therrien J, Gatzoulis M, Graham T, Bink-Boelkens M, Connelly M, Niwa K, Mulder B, Pyeritz R, Perloff J. Somerville J. Webb GD. Canadian Cardiovascular Society Consensus Conference 200I update: Recommendations for the Management of Adults with Congenital Heart Disease - Part II. Can J Cardiol. 2001;17:1029-50.

30. Pyeritz RE. Maternal and fetal complications of pregnancy in the Marfan syndrome. Am J Med. 1981;71:784-90

31. Meijboom LJ, Vos FE, Timmermans J, Boers GH, Zwinderman AH, Mulder BJ. Pregnancy and aortic root growth in the Marfan syndrome: a prospective study. Eur Heart 2005;26:9|4-20.

32. Lao TT, Sermer M, MaGee L, Farine D, Colman JM. Congenital aortic stenosis and pregnancy - a reappraisal. Am J Obstet Gynecol. 1993; 169:540-5.

33. Yap SC, Drenthen W, Pieper PG, Moons P, Mulder BI, Mostert B, Vliegen HW, van Dijk AP, Meijboom FJ, Steegers EA, Roos-Hesselink JW. Risk of complications during pregnancy in women with congenital aortic stenosis. Int J Cardiol. 2007.

34. Presbitero P, Prever SB, Brusca A. Interventional cardiology in pregnancy. Eur Heart J. 1996; 17:182-8.

35. Bhargava B, Agarwal R, Yadav R, Bahl VK, Manchanda SC. Percutaneous balloon aortic valvuloplasty during pregnancy: use of the Inoue balloon and the physiologic antegrade approach. Cathet Cardiovasc Diagn. 1998:45:422-5.

36. Horstkotte D, Fassbender D, Piper C. Balloon valvotomy during pregnancy. J Heart Valve Dis. $2005 ; 14: 144-6$.

37. Esteves CA, Munoz IS, Braga S, Andrade J, Meneghelo Z, Gomes N, Maldonado M, Esteves V, Sepetiba R, Sousa JE, Palacios IF. Immediate and long-term follow-up of percutaneous balloon mitral valvuloplasty in pregnant patients with rheumatic mitral stenosis. Am J Cardiol. 2006;98:8/2-6

38. Elkayam U, Bitar F.Valvular heart disease and pregnancy part I: native valves. J Am Coll Cardiol. 2005;46:223-30.

39. Beauchesne LM, Connolly HM, Ammash NM, Warnes CA. Coarctation of the aorta: outcome of pregnancy. I Am Coll Cardiol. 2001;38:1728-33.

40. Vriend JW, Drenthen W, Pieper PG, Roos-Hesselink JW, Zwinderman AH, van Veldhuisen DJ, Mulder BJ. Outcome of pregnancy in patients after repair of aortic coarctation. Eur Heart J. 2005;26:2173-8.

41. Veldtman GR, Connolly HM, Grogan M. Ammash NM, Warnes CA. Outcomes of pregnancy in women with tetralogy of Fallot. J Am Coll Cardiol. 2004;44: 174-80.

42. Beauchesne LM, Warnes CA, Connolly HM, Ammash NM, Grogan M, Jalal SM, Michels WV. Prevalence and clinical manifestations of 22q 1.2 microdeletion in adults with selected conotruncal anomalies. J Am Coll Cardiol. 2005;45:595-8.

43. AvilaWS, Grinberg M, Snitcowsky R, Faccioli R, Da Luz PL, Bellotti G, Pileggi F. Maternal and fetal outcome in pregnant women with Eisenmenger's syndrome. Eur Heart J. 1995; 16:460-4

44. Gleicher N, Midwall J, Hochberger D, Jaffin H. Eisenmenger's syndrome and pregnancy Obstet Gynecol Surv. 1979;34:721-41.

45. Presbitero P, Rabajoli F, Somerville J. Pregnancy in patients with congenital heart disease. Schweiz Med Wochenschr. 1995; 125:31 I-5.

46. Weiss BM,Zemp L, Seifert B, Hess OM. Outcome of pulmonary vascular disease in pregnancy: a systematic overview from 1978 through 1996. J Am Coll Cardiol. 1998;31:1650-7.

47. Bendayan D, Hod M, Oron G, Sagie A, Eidelman L, Shitrit D, Kramer MR. Pregnancy outcome in patients with pulmonary arterial hypertension receiving prostacyclin therapy. Obstet Gynecol. 2005; 106:1206-10.

48. Drenthen W, Pieper PG, Ploeg M, Voors AA, Roos-Hesselink JW, Mulder BJ, Vliegen HW, Sollie KM, Ebels T, van Veldhuisen D. Risk of complications during pregnancy after Senning or Mustard (atrial) repair of complete transposition of the great arteries. Eur Heart J. 2005;26:2588-95

49. Canobbio MM, Morris CD, Graham TP, Landzberg MJ. Pregnancy outcomes after atrial repair for transposition of the great arteries. Am J Cardiol. 2006;98:668-72.

50. Drenthen W, Pieper PG, Roos-Hesselink JW, van Lottum WA, Voors AA, Mulder BJ, van Dijk AP, Vliegen HW, Sollie KM, Moons P, Ebels T, van Veldhuisen DJ. Pregnancy and delivery in women after Fontan palliation. Heart. 2006;92: 1290-4.

5I. Jamieson WR, Miller DC, Akins CW, Munro Al, Glower DD, Moore KA, Henderson C. Pregnancy and bioprostheses: influence on structural valve deterioration. Ann Thorac Surg. 1995;60:S282-6; discussion S287.

52. Dore A, Somerville J. Pregnancy in patients with pulmonary autograft valve replacement. Eur Heart J. 1997; 1 8:1 659-62

53. Martin TC, Idahosa V, Ogunbiyi A, Fevrier-Roberts G, Winter A. Successful pregnancy and delivery after pulmonary autograft operation (Ross procedure) for meumatic aortic valve insufficiency. West Indian Med J. 2003;52:62-4.

54. Cooper WO, Hernandez-Diaz S, Arbogast PG, Dudley JA, Dyer S, Gideon PS, Hall K, Ray WA. Major congenital malformations after first-trimester exposure to ACE inhibitors. N Engl J Med. 2006;354:2443-5I.

55. Shannon ME, Malecha SE, Cha AJ. Beta blockers and lactation: an update. J Hum Lact 2000; 16:240-5.

56. Montan S. Drugs used in hypertensive diseases in pregnancy. Curr Opin Obstet Gynecol. 2004; | 6: I | |-5.

57. Chan WS. What is the optimal management of pregnant women with valvular heart disease in pregnancy? Haemostasis. 1999;29 Suppl SI:105-6.
58. Chan KY, Gilbert-Barness E, Tiller G. Warfarin embryopathy. Pediatr Pathol Mol Med. 2003;22:277-83

59. Ginsberg JS, Chan WS, Bates SM, Kaatz S. Anticoagulation of pregnant women with mechanical heart valves. Arch Intern Med. 2003;1 63:694-8.

60. Vahanian A, Baumgartner H, Bax J, Butchart E, Dion R, Filippatos G, Flachskampf F, Hall R, lung B, Kasprzak J, Nataf P,Tornos P,Torracca L, Wenink A, Priori SG, Blanc J), Budaj A, Camm J. Dean V. Deckers J. Dickstein K, Lekakis J, McGregor K, Metra M, Morais J. Osterspey A Tamargo J, Zamorano JL, Zamorano JL, Angelini A, Antunes M, Fernandez MA, GohlkeBaerwolf C, Habib G, McMurray J, Otto C, Pierard L, Pomar JL, Prendergast B, Rosenhek R, Uva MS, Tamargo I. Guidelines on the management of valvular heart disease:The Task Force on the Management of Valvular Heart Disease of the European Society of Cardiology. Eur Heart J. 2007;28:230-68.

61. Wilson W, Taubert KA, Gewitz M, Lockhart PB, Baddour LM, Levison M, Bolger A, Cabell CH, Takahashi M, Baltimore RS, Newburger IW, Strom BL, Tani LY, Gerber M, Bonow RO, Pallasch T, Shulman ST, Rowley AH, Burns JC, Ferrieri P, GardnerT, Goff D, Durack DT. Prevention of Infective Endocarditis. Guidelines From the American Heart Association. A Guideline From the American Heart Association Rheumatic Fever, Endocarditis, and Kawasaki Disease Committee, Council on Cardiovascular Disease in the Young, and the Council on Clinical Cardiology, Council on Cardiovascular Surgery and Anesthesia, and the Quality of Care and Outcomes Research Interdisciplinary Working Group. Circulation. 2007.

62. Schott J, Benson DW, Basson CT, Pease W, Silberbach GM, Moak JP, Maron BJ, Seidman CE, Seidman JG. Congenital heart disease caused by mutations in the transcription factor NKX2-5. Science. 1998:281:108-11.

63. Benson DW, Silberbach GM, Kavanaugh-McHugh A, Cottrill C, Zhang Y, Riggs S, Smalls O, Johnson MC, Watson MS, Seidman JG, Seidman CE, Plowden J, Kugler JD. Mutations in the cardiac transcription factor NKX2.5 affect diverse cardiac developmental pathways. J Clin Invest. 1999; 104: 1567-73.

64. Goldmuntz E, Geiger E, Benson DW. NKX2.5 mutations in patients with tetralogy of fallot. Circulation. 200I; 104:2565-8.

65. Watanabe Y, Benson DW, Yano S, Akagi T, Yoshino M, Murray JC. Two novel frameshift mutations in NKX2.5 result in novel features including visceral inversus and sinus venosus type ASD. J Med Genet. 2002;39:807-II

66. Muncke N, Jung C, Rudiger H, Ulmer H, Roeth R, Hubert A, Goldmuntz E, Driscoll D, Goodship J, Schon K, Rappold G. Missense mutations and gene interruption in PROSIT240, a novel TRAP240-like gene, in patients with congenital heart defect (transposition of the great arteries). Circulation. 2003; 108:2843-50.

67. Pizzuti A, Sarkozy A, Newton AL, Conti E, Flex E, Digilio MC, Amati F, Gianni D, Tandoi C, Marino B, Crossley M, Dallapiccola B. Mutations of ZFPM2/FOG2 gene in sporadic cases of tetralogy of Fallot. Hum Mutat. 2003;22:372-7.

68. McElhinney DB, Krantz ID, Bason L, Piccoli DA, Emerick KM, Spinner NB, Goldmuntz E. Analysis of cardiovascular phenotype and genotype-phenotype correlation in individuals with a JAGI mutation and/or Alagille syndrome. Circulation. 2002:106:2567-74.

69. Robinson SW, Morris CD, Goldmuntz E, Reller MD, Jones MA, Steiner RD, Maslen CL. Missense mutations in CRELDI are associated with cardiac atrioventricular septal defects. Am J Hum Genet. 2003;72: 1047-52.

70. Basson CT, Huang T, Lin RC, Bachinsky DR, Weremowicz S, Vaglio A, Bruzzone R, Quadrelli R, Lerone M, Romeo G, Silengo M, Pereira A, Krieger J, Mesquita SF, Kamisago M, Morton CC, Pierpont ME, Muller CW. Seidman JG, Seidman CE. Different TBX5 interactions in heart and limb defined by Holt-Oram syndrome mutations. Proc Natl Acad Sci U S A. 1999;96:2919-24

71. Tartaglia M, Mehler EL, Goldberg R, Zampino G, Brunner HG, Kremer H, van der Burgt I, Crosby AH, lon A, Jeffery S, Kalidas K, Patton MA, Kucherlapati RS, Gelb BD. Mutations in PTPNI I, encoding the protein tyrosine phosphatase SHP-2, cause Noonan syndrome. Nat Genet. 200 1;29:465-8.

72. Schubbert S, Zenker M, Rowe SL, Boll S, Klein C, Bollag G, van der Burgt I, Musante L, Kalscheuer V, Wehner LE, Nguyen H, West B, Zhang KY, Sistermans E, Rauch A, Niemeyer CM, Shannon K, Kratz CP. Germline KRAS mutations cause Noonan syndrome. Nat Genet. 2006:38:331-6.

73. Dietz HC, Pyeritz RE, Hall BD, Cadle RG, Hamosh A, Schwartz J, Meyers DA, Francomano CA. The Marfan syndrome locus: confirmation of assignment to chromosome 15 and identification of tightly linked markers at |5q | 5-q21.3. Genomics. |99|;9:355-61.

74. MizuguchiT, Collod-Beroud G,AkiyamaT,Abifadel M, Harada N, MorisakiT,Allard D,Varret M, Claustres M, Morisaki H, Ihara M, Kinoshita A, Yoshiura K, Junien C, Kajii T, Jondeau G, Ohta T, Kishino T, Furukawa Y, Nakamura Y, Niikawa N, Boileau C, Matsumoto N. Heterozygous TGFBR2 mutations in Marfan syndrome. Nat Genet. 2004:36:855-60.

75. Niihori T, Aoki Y, Narumi Y, Neri G, Cave H, Verloes A, Okamoto N, Hennekam RC, Gillessen-Kaesbach G,Wieczorek D, Kavamura MI, Kurosawa K, Ohashi H,Wilson L, Heron D, Bonneau D, Corona G, Kaname T, Naritomi K, Baumann C, Matsumoto N, Kato K, Kure S, Matsubara Y. Germline KRAS and BRAF mutations in cardio-facio-cutaneous syndrome. Nat Genet. 2006;38:294-6.

76. Rodriguez-Viciana P,Tetsu O,Tidyman WE, Estep AL, Conger BA, Cruz MS, McCormick F, Rauen KA. Germline mutations in genes within the MAPK pathway cause cardio-faciocutaneous syndrome. Science. 2006;31 I:1 287-90

77. Legius E, Schrander-Stumpel C, Schollen E, Pulles-Heintzberger C, Gewillig M, Fryns JP. PTPNI I mutations in LEOPARD syndrome. J Med Genet. 2002;39:57I -4. 